\title{
Removal of bovine digital dermatitis- associated treponemes from hoof knives after foot-trimming: a disinfection field study
}

\author{
A. V. Gillespie ${ }^{1 *}$ (D, S. D. Carter ${ }^{1}$, R. W. Blowey², G. J. Staton ${ }^{1}$ and N. J. Evans ${ }^{1}$
}

\begin{abstract}
Background: Bovine digital dermatitis (BDD) is an infectious foot disease found commonly in dairy herds. Foottrimming is an important husbandry procedure for reducing the ensuing lameness; however, epidemiological, and microbiological studies have identified this as a risk activity for transmitting BDD.

Three disinfectants have previously been identified in laboratory work as effective for removing viable BDD-associated Treponema spp., from hoof knife blades. The present study enrolled 133 dairy cattle with BDD lesions, and swabbed hoof knife blades before and after foot-trimming, and after knife disinfection with one of three disinfectants (1:100

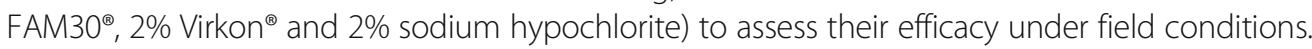

Results: Detection of BDD treponeme phylogroup DNA was undertaken by direct PCR of swabs, and viable treponemes were detected by PCR of swab cultures after 6 weeks' incubation.

Where hoof knives did not contact the lesion, BDD-associated treponemes were detected after foot-trimming in 12/22 (54.5\%) cases by direct PCR and 1/22 (4.5\%) cases by PCR of cultured organisms. Where contact was made with the lesion, 111/111 (100\%) samples taken after trimming were positive by direct PCR and 47/118 (39.8\%) were positive by culture PCR. Viable organisms were identified in cultures from lesion stages M2, M3, M4 and M4.1. No viable organisms were detected after disinfection of hoof knives.

Conclusions: Hoof knives post-trimming were frequently contaminated with BDD-associated treponeme DNA. Viable organisms were identified in cultures whether contact had been made between hoof knife and lesion or not, although contact clearly increased the frequency of detection of viable organisms. The three disinfectants tested were effective for removing viable organisms. The disinfection protocol used in this study should therefore be considered reliable for adoption as standard industry practice.
\end{abstract}

Keywords: Dairy cattle, Digital dermatitis, Bovine, Treponemes, Disinfection, Hoof knives, Foot-trimming

\footnotetext{
* Correspondence: amyg@liverpool.ac.uk

'Department of Infection Biology, Institute of Infection and Global Health, University of Liverpool, Merseyside, UK

Full list of author information is available at the end of the article
}

(c) The Author(s). 2020 Open Access This article is licensed under a Creative Commons Attribution 4.0 International License, which permits use, sharing, adaptation, distribution and reproduction in any medium or format, as long as you give appropriate credit to the original author(s) and the source, provide a link to the Creative Commons licence, and indicate if changes were made. The images or other third party material in this article are included in the article's Creative Commons licence, unless indicated otherwise in a credit line to the material. If material is not included in the article's Creative Commons licence and your intended use is not permitted by statutory regulation or exceeds the permitted use, you will need to obtain permission directly from the copyright holder. To view a copy of this licence, visit http://creativecommons.org/licenses/by/4.0/. The Creative Commons Public Domain Dedication waiver (http://creativecommons.org/publicdomain/zero/1.0/) applies to the data made available in this article, unless otherwise stated in a credit line to the data. 


\section{Background}

Bovine digital dermatitis (BDD) is an infectious foot disease found commonly in dairy herds. This important, painful cattle disease was first reported in 1974 in Italy [1] and has since been recognised globally [2-4]. Herdlevel prevalence has been reported in the range 63.8$97.4 \%$, indicating BDD is endemic in many countries [58]. Typically, BDD lesions are found affecting the skin between the heel bulbs. Their clinical appearance has been described and classified into five lesion stages, beginning with a small, focal active lesion (M1), through the larger active ulcerative stage (M2), to the healing stage (M3). Lesions often become chronic, forming hyperkeratotic scabs (M4), from which state they can 'reactivate' with small focal active lesions superimposed (M4.1) $[9,10]$.

Spirochaetal bacteria are consistently found in BDD lesions and are implicated as primary pathogens in the disease. Studies of BDD-associated spirochaetes, through sequence analysis of the 16S rRNA gene, identified several phylogroups of bacteria from the Treponema genus closely related to the human oral treponemes, Treponema denticola and Treponema vincentii, as well as the non-pathogenic Treponema phagedenis, originally isolated from the human urogenital tract $[11,12]$. Subsequently, studies have identified three of these phylogroups consistently within BDD lesions and more detailed analyses have led to their classification as: Treponema medium/vincentii-like, Treponema phagedenis and Treponema pedis [13-15]. These three diverse treponemal phylogroups are strongly associated with BDD lesions and are considered to work synergistically to increase disease severity [16].

There are several on-farm risk factors associated with the development of BDD; predominantly housing and environmental factors [17]. A substantial collective of literature has resulted in industry recommendations to concentrate on improving farm environmental hygiene to control BDD. The existing paradigm is that infection is spread predominantly from M2 and M4 lesions to healthy feet via the environment; however, treponemes have not been isolated in culture or detected by PCR from farm environments [18]. Hence, questions remain about the importance of slurry and the environment in disease transmission. Current industry advice regarding better slurry management may be beneficial as it may reduce the susceptibility of skin to invasion by treponemes, and effective footbathing protocols have generally proved useful in reducing case numbers; however, there are additional infection reservoirs which may be key to BDD control initiatives.

Epidemiological studies have previously identified the use of external foot-trimmers as a risk factor for higher numbers of BDD cases in affected herds $[8,19]$. With dairy farm expansion and amalgamation across the last 50 years, use of external foot-trimmers operating highthroughput systems, where large numbers of cows are trimmed in succession, has increased. Previous work detected BDD-associated treponemes on hoof knives using PCR, raising concerns that these tools, which are moved quickly and frequently from foot-to-foot, may act as a fomite for BDD-associated treponemes and could be having an impact on case numbers in these systems [20]. BDD-associated Treponema have also been identified on hoof-trimming equipment using $16 \mathrm{~S}$ rRNA gene sequencing [21]. It is not known, however, whether Treponema detected by PCR or 16S rRNA sequencing correspond to the presence of viable infectious organisms [20], and if they are viable, whether they remain at sufficient numbers to constitute an infectious dose. BDD treponemes are known to survive on hoof knife blades under aerobic laboratory conditions for up to $2 \mathrm{~h}$ suggesting they could be viable under field conditions and transferable between feet via hoof knives [22].

Laboratory work testing disinfectants against a Treponema phagedenis-like spirochaete to determine minimum inhibitory concentrations and minimum bactericidal concentrations showed a range of disinfectants to be effective even in the presence of $20 \%$ manure [23]. Subsequently, in laboratory bacterial challenge experiments, three disinfectants were identified as good candidates for hoof knife disinfection using a $20 \mathrm{~s}$ contact time [22]. The current study tests these three disinfectants; - 1:100 FAM $30^{\circ}, 2 \%$ Virkon $^{\bullet}$ and $2 \%$ sodium hypochlorite, under field conditions during foot-trimming of dairy cattle.

\section{Results}

A total of 133 BDD cases with the following pathological lesion stages were used to collect samples: one M1, 11 M2, 10 M3, 101 M4 and 10 M4.1 (Table 3). One of three disinfectants was used on trimming blades for 86 cases, whilst water was used in the remaining 47 cases. For 22 cases, no blade contact was made with the BDD lesion during foot-trimming (Fig. 1), whilst for the remaining 111 cases blade contact was made with the lesion (Fig. 2, Table 2), which was done to remove crusting from lesions prior to the application of topical treatment (Terramycin Aerosol Spray, Zoetis, UK).

Where contact was not made with BDD lesions, 18/22 $(81.8 \%)$ of post-trimming swabs taken directly from the hoof knife blades tested positive (using nested PCR) for the Treponema genus, and 12/22 (54.5\%) tested DNA positive for at least one of the three pathogenic Treponeme phylogroups after trimming (Fig. 1). After disinfection, 17/22 (77.3\%) remained DNA positive for the Treponema genus and 10/22 (45.5\%) remained DNA positive for at least one of the three pathogenic phylogroups. All knives cleaned with water-9/9 (100\%)- and 


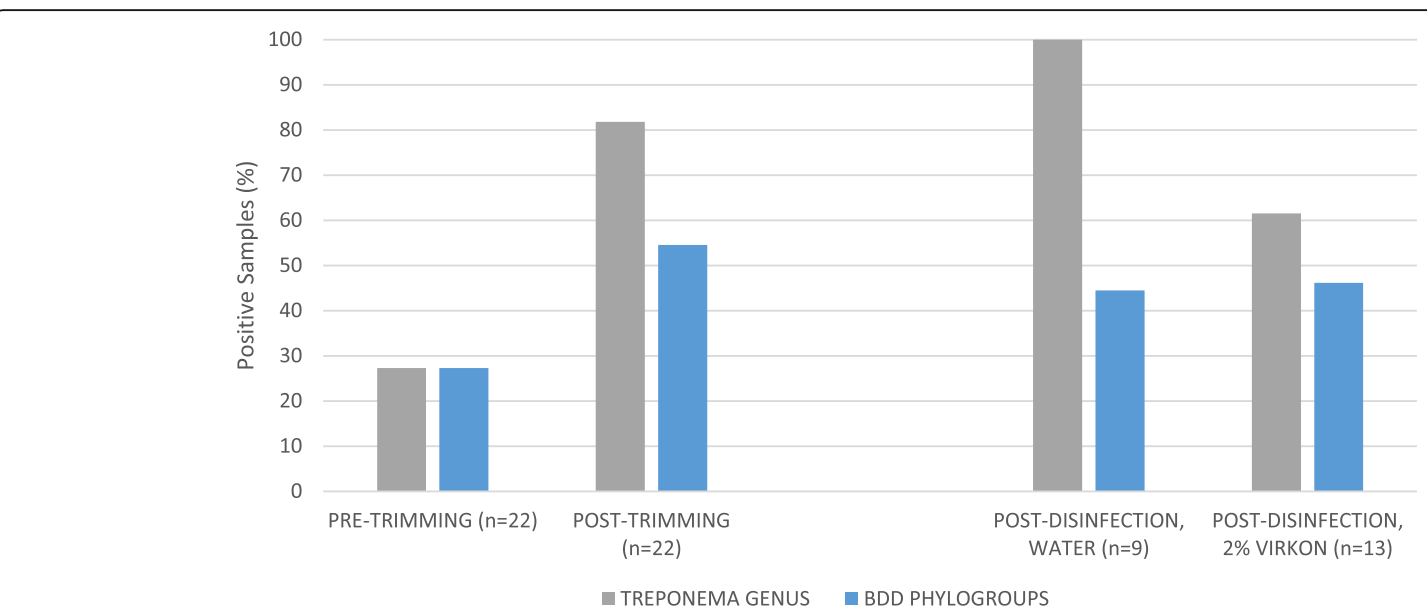

Fig. 1 Direct PCR results showing disinfectant efficacy (no contact made between hoof knives and BDD lesions). Treponema DNA Positive Samples (\%) identified by direct PCR showing efficacy of $2 \%$ Virkon ${ }^{\circledR}$ compared to water for disinfection of hoof knife blades for removal of Treponema genus DNA and DNA from three BDD-associated treponeme phylogroups. No contact was made between the hoof knife blades and the BDD lesions $(n=22)$

$8 / 13$ (61.5\%) of those disinfected with $2 \%$ Virkon $^{\circ}$ remained DNA positive for the Treponema genus. The number of knives testing positive for BDD phylogroup DNA post-cleaning with water increased from $2 / 9$ (22.2\%) to $4 / 9$ (44.4\%), whilst disinfection using $2 \%$ Vir$\mathrm{kon}^{\circ}$ reduced the number of positive samples from 10/ $13(76.9 \%)$ to $6 / 13$ (46.2\%) (Fig. 1). Some samples taken pre-trimming $(6 / 22 ; 27.3 \%)$ tested DNA positive for Treponema genus and BDD phylogroups, suggesting some hoof knife blades were contaminated prior to trimming, including some that had not been previously used for hoof trimming that day.
Post swab culture (6 weeks), where no blade contact was made with BDD lesions, the Treponema genus and pathogenic treponeme DNA were detected in only $1 / 22$ (4.5\%) cases after trimming, indicating a low incidence of living organisms when sampled. Disinfection using $2 \%$ Virkon $^{\circ}$ removed culturable organisms in this case. No samples taken pre-trimming were found to contain culturable treponemes.

Where blade contact was made with BDD lesions (Fig. 2), all swabs (111/111) taken after trimming were DNA positive (using nested PCR) for the Treponema genus and at least one of the three pathogenic phylogroups.

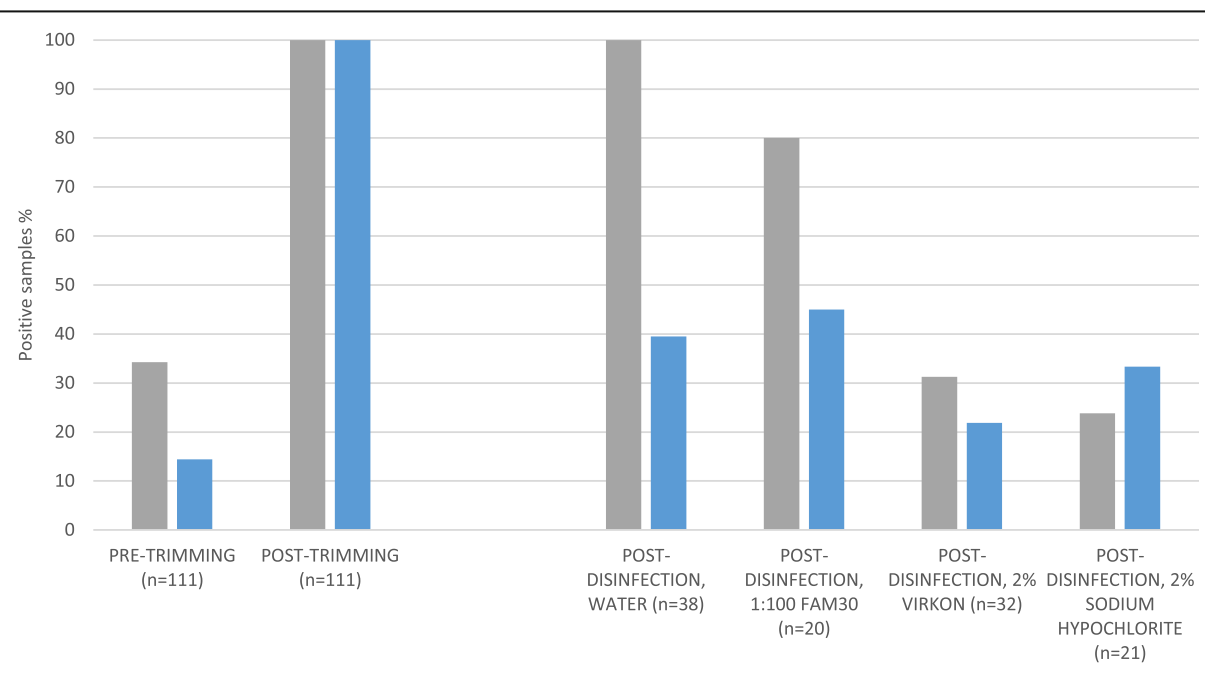

-TREPONEMA GENUS $=$ BDD PHYLOGROUPS

Fig. 2 Direct PCR results showing disinfectant efficacy (contact made between hoof knives and BDD lesions). Treponema DNA Positive Samples (\%) identified by direct PCR, showing efficacy of three disinfectants (compared to water) for disinfection of hoof knife blades for removal of Treponema genus DNA and DNA from three BDD-associated treponeme phylogroups. Contact was made between the hoof knife blades and the BDD lesions $(n=111)$ 
After disinfection, 69/111 (62.2\%) remained PCR positive for the Treponema genus and 38/111 (34.2\%) for at least one of the pathogenic phylogroups. Knives cleaned with water or disinfected with 1:100 FAM $30^{\circ}$ frequently remained contaminated with Treponema genus DNA $(38 / 38(100 \%)$ and $16 / 20(75 \%)$ of samples respectively). They also performed less well for removing BDD phylogroup DNA; with 15/38 (39.5\%) and 9/20 (45.0\%) samples remaining positive (Fig. 2). Univariable logistic regression showed that when knives were disinfected using $2 \%$ sodium hypochlorite or $2 \%$ Virkon ${ }^{\circ}$ (compared to water) they had decreased odds of testing PCR positive for BDD-associated phylogroup and/ or Treponema genus DNA (Table 1).

For swabbing of blades where lesion contact was made, as found for the samples where no contact was made between the hoof knives and the BDD lesions, some samples taken pre-trimming tested positive for the Treponema genus (38/111 (34.2\%)) and BDD phylogroups (16/111 (14.4\%)), indicating some hoof knife blades had become contaminated prior to trimming (Fig. 2). Positive pre-trimming samples came both from knives that were being used for the first time that day, and from knives that had already been used for foottrimming during the session. However, Table 2 shows that these treponemes were not viable.

Where contact was made with BDD lesions $(n=111)$, the Treponema genus was detected by nested PCR of six-week cultures in 64/111 (57.7\%) of cases and BDDassociated treponemes were detected in 47/111 (42.3\%) of cases after trimming. Univariable logistic regression showed that making contact between the hoof knife blade and the lesion was statistically more likely to result in a positive culture (Odds Ratio 3.39, 95\% confidence interval 1.35-5.43, $P=0.001)$. All three disinfectants (and water) were effective at removing culturable organisms (Table 2).

In an analysis of treponemes on blades used to trim different lesion stages, there was a clear presence at all $M$ grades (Table 3). All BDD lesion stages showed detection of BDD treponemes in post-trimming cultures, except for a single M1 case in which there was no contact between the hoof knife blade and the lesion. Some lesion stages yielded higher proportions of positive cultures: 80 ,
75 and $66.7 \%$ from M2, 3 and 4.1 lesions respectively compared to $36.2 \%$ for chronic M4 cases; however, univariable logistic regression did not show these differences to be statistically significant.

A comprehensive list of cases showing both direct PCR and culture PCR results is available in Table 1 in Additional file 1.

\section{Discussion}

This study has confirmed our previous work that the BDD-associated treponemes present in BDD lesions are readily transferrable to hoof trimming blades and can be viable and transmissible. Importantly, it has also shown, in field studies, that even brief disinfection of the blades (at shorter than typically recommended contact times) is very efficient in eliminating viable treponemes from blades and presumably blocking at least this route of BDD transmission. This is a very practical outcome worthy of consideration for best practice as it can be performed with minimal effort or investment.

In over $90 \%$ of samples, direct nested PCR testing detected post-trimming contamination of hoof knives with the Treponema genus DNA and at least one of the three culturable BDD-associated treponeme phylogroups. This is consistent with findings from previous field work [20] and the present study achieved similar overall disinfection efficacy for the BDD phylogroups as determined by the presence of BDD treponeme DNA within swab samples. However, detection of bacterial DNA direct from swabs does not assess the viability of organisms and therefore does not indicate whether they might be capable of transmission. For this reason, we introduced the use of bacterial culture of blade swabs, which showed that in 48/133 (36.1\%) cases, post-trimming hoof knives were contaminated with BDD phylogroup treponemes that were viable. This is surprisingly high considering that treponemes are notoriously fastidious [13] and therefore their survival during sample collection and transport under aerobic conditions (especially when they are considered to be anaerobic organisms) would be expected to be low [24]. In addition, field samples inevitably contain many contaminating bacteria that could be expected to out-compete treponemes in culture. For these reasons, those samples where treponeme DNA was

Table 1 Results of univariable logistic regression showing decreased odds of detection of Treponema genus and/ or BDD-associated phylogroup DNA where $2 \%$ sodium hypochlorite or $2 \%$ Virkon $^{\oplus}$ were used to disinfect hoof knives compared to water

\begin{tabular}{lllll}
\hline Disinfectant & Odds Ratio & 95\% Confidence Interval & P-value & Standard Error \\
\hline 1:100 FAM30 & -2.09 & $-4.42-0.24$ & 0.078 & 1.19 \\
2\% sodium hypochlorite & -4.31 & $-6.48--2.15$ & $<0.001$ & 1.11 \\
2\% Virkon ${ }^{\oplus}$ & -4.23 & $-6.30--2.16$ & $<0.001$ & 1.06 \\
Baseline & 3.83 & $1.85-5.81$ & & 1.01 \\
\hline
\end{tabular}


Table 2 Treponema PCR results for swab cultures showing disinfectant efficacy where contact was made between hoof knives and BDD lesions. The effect of disinfectants on viable treponemes on hoof trimming knives (determined by PCR of cultures), swabbed before use, and again post-trimming and post-disinfection. In all samples knife-BDD lesion contact occurred during trimming

\begin{tabular}{|c|c|c|c|c|c|c|}
\hline \multirow[t]{2}{*}{ Disinfectant } & \multicolumn{2}{|c|}{ PRE-TRIMMING } & \multicolumn{2}{|c|}{ POST-TRIMMING } & \multicolumn{2}{|c|}{ POST-DISINFECTION } \\
\hline & $\begin{array}{l}\text { Treponema } \\
\text { genus }\end{array}$ & $\begin{array}{l}\text { BDD } \\
\text { phylogroups }\end{array}$ & $\begin{array}{l}\text { Treponema } \\
\text { genus }\end{array}$ & $\begin{array}{l}\text { BDD } \\
\text { phylogroups }\end{array}$ & $\begin{array}{l}\text { Treponema } \\
\text { genus }\end{array}$ & $\begin{array}{l}\text { BDD } \\
\text { phylogroups }\end{array}$ \\
\hline $2 \%$ Virkon $^{\oplus} n=32$ & $0 / 32$ & $0 / 32$ & 18/32 (56.3\%) & 13/32 (40.6\%) & $0 / 32$ & $0 / 32$ \\
\hline $\begin{array}{l}2 \% \text { sodium hypochlorite } n= \\
21\end{array}$ & $0 / 21$ & $0 / 21$ & 10/21 (47.6\%) & 10/21 (47.6\%) & $0 / 21$ & $0 / 21$ \\
\hline 1:100 FAM $30^{\oplus} n=20$ & $0 / 20$ & $0 / 20$ & $12 / 20(60.0 \%)$ & $10 / 20(50.0 \%)$ & $0 / 20$ & $0 / 20$ \\
\hline Water $n=38$ & $0 / 38$ & $0 / 38$ & 24/38 (63.2\%) & 14/38 (36.8\%) & $0 / 38$ & $0 / 38$ \\
\hline Total $(n=111)$ & $0 / 111$ & $0 / 111$ & $64 / 111$ (54.2\%) & 47/111 (39.8\%) & $0 / 111$ & $0 / 111$ \\
\hline
\end{tabular}

detected but cultures were negative should not automatically be regarded as not containing viable treponemes. In particular, the lower probability of culturing treponemes where no knife contact was made with lesions was unsurprising as lesions are the major source of bacteria, and a reduction in the number of positive cultures could be expected due to reduced bacterial load.

It was confirmed, by univariable logistic regression, that contact with the BDD lesions during foot-trimming increases the frequency of culturable BDD-associated treponemes. Infection rates may also vary according to BDD prevalence on farm; furthermore, management measures taken to reduce environmental bacterial load are likely to reduce foot infections. For example, recently footbathed feet may have fewer viable treponemes, which would result in a reduction in new BDD cases observed [25].

In this study, water was equally as effective at removing viable treponemes from hoof knives as any of the three disinfectants tested, although the sample size may be too small to differentiate. Water was not successful during laboratory testing where the majority of knives remained contaminated with viable treponemes; however, the in vitro experiments were carried out using pure treponeme cultures and are likely to represent a greater bacterial load [22]. Nevertheless, in case of greater bacterial challenge on the farm than that encountered in this trial, water should still be considered inferior to the three disinfectants for hoof knife disinfection given the previous laboratory collected data and the potential for presence of other bacteria likely to contribute to BDD lesions.

FAM $30^{\circ}$ was effective for removing viable treponemes but did not perform as well as the other disinfectants for removing DNA detectable by direct PCR. The same in vitro study found that FAM $30^{\circ}$ failed to eliminate Treponema phagedenis or Treponema pedis DNA from hoof knife blades despite removing all viable bacteria [22]. Whilst the current study does not have the power to differentiate the ability of each disinfectant to remove

Table 3 Detection of BDD treponeme phylogroups according to lesion stage. The effect of BDD lesion stage on detection of BDD treponeme phylogroups in post-trimming and post-disinfection hoof knife swab samples (disinfected using water, $2 \%$ Virkon ${ }^{\oplus}, 2 \%$ sodium hypochlorite or 1:100 FAM30 ${ }^{\circledR}$ ) as measured by both direct and post-culture PCR

\begin{tabular}{|c|c|c|c|c|c|}
\hline Lesion Type & $\begin{array}{l}\text { Contact with lesion } \\
\text { (Yes/No) }\end{array}$ & $\begin{array}{l}\text { Post-trimming Direct } \\
\text { PCR }\end{array}$ & $\begin{array}{l}\text { Post-disinfection Direct } \\
\text { PCR }\end{array}$ & $\begin{array}{l}\text { Post-trimming Culture } \\
\text { PCR }\end{array}$ & $\begin{array}{l}\text { Post-disinfection } \\
\text { Culture PCR }\end{array}$ \\
\hline $\mathrm{M} 1(n=1)$ & No & 1/1 (100\%) & $1 / 1(100 \%)$ & 0 & 0 \\
\hline $\mathrm{M} 2(n=7)$ & No & $3 / 7$ (42.9\%) & 2/7 (28.6\%) & 0 & 0 \\
\hline $\mathrm{M} 2(n=5)$ & Yes & $5 / 5(100 \%)$ & $2 / 5$ (40.0\%) & $4 / 5(80.0 \%)$ & 0 \\
\hline $\mathrm{M} 3(n=6)$ & No & 4/6 (66.7\%) & $3 / 6(50.0 \%)$ & $1 / 6(16.7 \%)$ & 0 \\
\hline $\mathrm{M} 3(n=4)$ & Yes & $4 / 4(100 \%)$ & $3 / 4$ (75.0\%) & $3 / 4(75.0 \%)$ & 0 \\
\hline$M 4(n=7)$ & No & $3 / 7$ (42.9\%) & $3 / 7$ (42.9\%) & 0 & 0 \\
\hline$M 4(n=94)$ & Yes & $94 / 94(100 \%)$ & 29/94 (40.4\%) & $34 / 94$ (36.2\%) & 0 \\
\hline$M 4.1(n=1)$ & No & $1 / 1(100 \%)$ & $1 / 1(100 \%)$ & 0 & 0 \\
\hline M4.1 $(n=9)$ & Yes & 9/9 (100\%) & $4 / 9(44.4 \%)$ & $6 / 9(66.7 \%)$ & 0 \\
\hline $\begin{array}{l}\text { All lesions }(n= \\
\text { 22) }\end{array}$ & No & $12 / 22(54.5 \%)$ & 10/22 (45.4\%) & $1 / 22(4.5 \%)$ & 0 \\
\hline $\begin{array}{l}\text { All lesions ( } n= \\
111)\end{array}$ & Yes & $111 / 111$ (100\%) & $38 / 111$ (34.2\%) & 47/111 (39.8\%) & 0 \\
\hline
\end{tabular}


culturable treponemes (since all were 100\% effective), it does show statistically significant differences between disinfectants in terms of successful removal of DNA (Table 1). Interpretation of these results is difficult because, as already stated, PCR positive results do not necessarily correspond to viable bacteria that could be capable of transmission; DNA can still be detected even when all bacteria are completely inactivated.

Positive cultures came from cases with M2, M3, M4 and M4.1 lesions. It has been shown that treponeme numbers are higher in active ulcerative lesions (as previously determined using qPCR to quantify bacterial DNA, rather than using culture) [16]. Our results indicate that higher percentages of M2, M3 and M4.1 lesions lead to positive cultures post-trimming when compared to the chronic M4 stage; however, this effect could be due to smaller sample sizes in the other lesion categories and overall insufficient sample size. This distribution of BDD lesion stages in the field is consistent with a recent study that classified $63.4 \%$ of heel bulb lesions as M4 [26], and a recent study of BDD transmission dynamics which found that about $70 \%$ of infected time was spent as M4 [27].

Pre-trimming contamination of hoof knives was an unexpected finding. It is possible that washing between cows was inadequate, and treponeme DNA was robust enough to remain intact after cleaning and immersion in $70 \%$ ethanol for $10 \mathrm{~min}$. This would not, on its own, be important for disease transmission (as no viable organisms were detected) but could explain our pre-trimming data sets. It is also possible that contamination was caused by aerosolisation of bacteria in the vicinity of the foot-trimming crush, contaminating knives as they were air dried for use. Although studies regarding bioaerosols on dairy farms are limited, it has been shown that Mycobacterium avium subsp. paratuberculosis can be detected in settled dust particles inside dairy housing 3 weeks after introduction of infected cattle [28]. Furthermore, spirochaetes have been identified in aerosols on a dairy farm, representing $1 \%$ of the total $16 \mathrm{~S}$ rRNA gene sequences identified in aerosol samples [29]. As pre-trimming contamination did not result in viable treponeme cultures, we consider aerosols have limited ability to transmit Treponema spp.

Coupled with previous findings that treponemes can survive on hoof knife blades for $2 \mathrm{~h}$ and subsequently be recovered in culture [22], the finding of viable treponemes post-trimming in field samples provides evidence that poor hygiene during hoof trimming is a risk factor for BDD transmission. BDD infection models have shown that existing tissue damage and direct contact with fresh lesional material containing a viable polytreponemal bacterial load is needed to cause lesion development [30-32]. Foot-trimming would appear to fulfil the criteria for the infection models as viable treponemes (and potentially other bacteria) may be transferred between the feet of cows in the herd trimmed in quick succession (assuming that effective disinfection is not practised), and these feet frequently demonstrate some evidence of damage either from slurry exposure or general mechanical damage. Consideration should also be given to other aspects of hygiene during foot-trimming, particularly cleanliness of gloves, since it has been shown that treponemes can survive on gloves for up to 3 days after handling sheep feet showing the analogous disease, contagious ovine digital dermatitis [24]. The use of disinfectants on trimming tools will not only assist in controlling transmission of treponemes between animals and farms but will also have the effect of reducing transmission of other microbes which are known to contribute to digital dermatitis and other important foot lesions [33].

\section{Conclusions}

Previous epidemiological studies identified use of an external foot-trimmer and lack of washing of hoof trimming equipment as risk factors for increased herd BDD prevalence $[8,19]$. The current study demonstrates high levels of pathogenic treponeme contamination on hoofknives post-trimming, including viable organisms, even where no contact has been made between the hoof knife and the BDD lesion. Collectively, the evidence provides a compelling argument for improving hygiene during foot-trimming. The disinfectants used here have been shown to be effective against BDD treponemes on hoof knives both in the laboratory [22] and on farm during foot-trimming of dairy cows with a short contact time of $20 \mathrm{~s}$ for removing viable treponemes. The disinfection protocol used in this study should therefore be considered reliable for adoption as standard industry practice.

\section{Methods \\ Sample collection}

The study included lactating dairy cattle during routine foot-trimming in three commercial farms (Cheshire and Gloucestershire, UK) where cows were housed in cubicles. The case definition was any foot showing visible BDD lesions of any pathological classification (M1, M2, M3, M4 or M4.1) [10]. Swab samples were taken during foot-trimming if a foot fitted the case definition. The hoof knives used belonged to the foot-trimmers who were participating in the study (Aesculap VC316V or VC300/ VC305, Neogen, USA). All foot-trimming was carried out according to the foot-trimmer's normal protocol. Initial studies were made where the knife blades either did or did not come into contact with BDD lesions during trimming. However, swabs of blades which did not make lesion contact had a very low culture rate of pathogenic treponemes meaning that that 
efficacy of disinfectants could not be assessed for this group. Consequently, the approach was revised so that in subsequent studies only cases where hoof knife contact had been made with a BDD lesion to remove crusting from lesions prior to the application of topical treatment (Terramycin Aerosol Spray, Zoetis, UK) were included.

At the beginning of each sample collection session and after each foot during foot-trimming, hoof knives were cleaned using household detergent in water (Fairy, Proctor \& Gamble, USA) then immersed in $70 \%$ ethanol for a minimum of $10 \mathrm{~min}$ and air-dried prior to use. Plain cotton swabs (Copan, Italy) were passed back and forth three times over the whole length of the front and back of hoof knife blades to serve as pre-trimming control samples. Three swabs were taken per blade: one for inoculation into Oral Treponeme Enrichment Broth (OTEB, Anaerobe systems, USA) containing 10\% heat-inactivated Foetal Calf Serum (FCS, Thermo Fisher Scientfic, USA), one for inoculation into OTEB containing 10\% heat- inactivated Rabbit Serum (RS, Firstlink, UK) and one for direct testing by nested PCR without prior culture. Swab samples from the knives were taken again once foot-trimming of each foot was completed. Knives were rinsed briefly in water (3 s) to remove gross contamination before immersing the blades in one of three disinfectants (2\% Virkon ${ }^{\circ}, 2 \%$ sodium hypochlorite, 1:100 $\mathrm{FAM}^{\circ} 0^{\circ}$ ) or water (as a comparison) for $20 \mathrm{~s}$. The short contact time was chosen as the aim was to evaluate a rapid disinfection protocol which could be used by foot-trimmers with minimal disruption to workflow eg. by using two knives alternatively with one in disinfectant. Following disinfection, blades were shaken dry and three swab samples taken for a third time. The number of blades disinfected with each agent, according to whether contact was made with the BDD lesion is shown in Fig. 3. The culture protocol was designed to favour growth of the three cultivable BDD treponeme phylogroups so that the effect of disinfection could be evaluated. Liquid medium containing FCS favours the growth of
T. phagedenis- like and T. pedis strains, whilst liquid medium containing RS favours growth of T. medium/ vincentii- like strains.

\section{Sample processing}

On farm knife swabs for culture were immediately inoculated into their designated medium (OTEB) in $2 \mathrm{ml}$ screw top tubes and transported at ambient temperature. On return to the laboratory they were placed in an anaerobic cabinet (Don Whitley Scientific, UK) $\left(85 \% \mathrm{~N}_{2}\right.$, $10 \% \mathrm{H}_{2}$ and $5 \% \mathrm{CO}_{2}, 36^{\circ} \mathrm{C}$ ) and rifampicin and enrofloxacin added to a final concentration of $5 \mu \mathrm{g} / \mathrm{ml}$ and $1 \mu \mathrm{g} / \mathrm{ml}$ respectively to suppress growth of contaminants. After 6 weeks in culture, bacterial genomic DNA (gDNA) was extracted from cultures using a Chelex resin (Biorad, USA) protocol according to manufacturer's instructions. Briefly, samples were boiled with the Chelex in a water bath for $15 \mathrm{~min}$, then centrifuged at $13,000 \mathrm{rpm}$ for $10 \mathrm{~min}$ [34]. Resulting gDNA-containing supernatant was frozen at $-20^{\circ} \mathrm{C}$.

Swabs for direct nested PCR analyses were placed on ice for transport and gDNA subsequently extracted using a DNeasy minikit (Qiagen, UK) according to manufacturer's instructions and stored at $-20^{\circ} \mathrm{C}$.

\section{PCR assays}

Detection of Treponema was undertaken via two methods: nested PCR of sample swabs taken directly from the hoof knife blades, and nested PCR of DNA extracted from cultures given 6 weeks to grow. The former method is very sensitive for detecting Treponema DNA and the latter provides a measure of treponemal viability determined by an ability to grow in liquid culture medium. Whilst in this study treponemes were not isolated and identified in pure culture, the continued presence of their DNA after 6 weeks was interpreted as evidence of viable growth, a measure previously shown to correlate with observation of live treponemes in culture using phase contrast microscopy [22, 24].

All gDNA samples were subjected to nested PCR assays to a) detect the Treponema genus, and to b) specifically detect each of the three cultivable BDD-associated

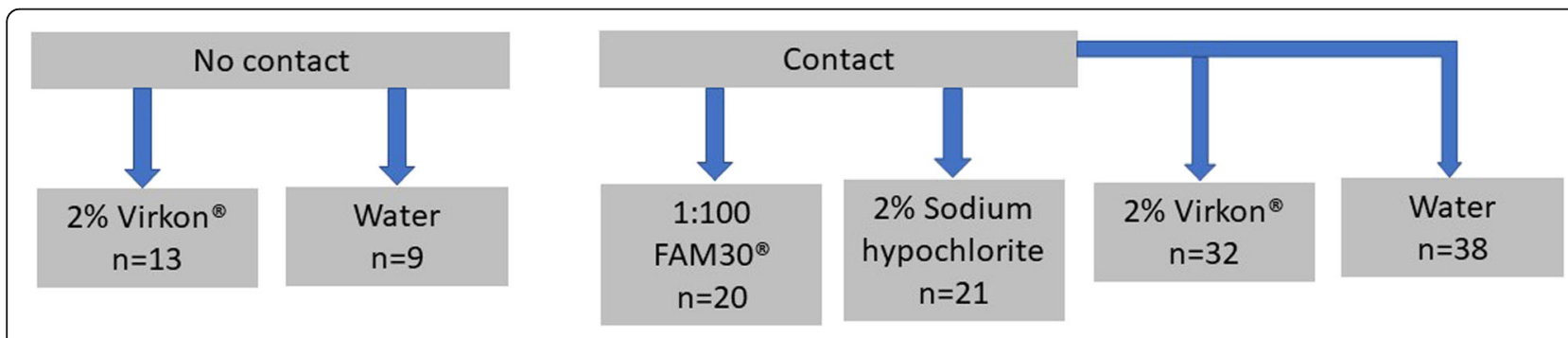

Fig. 3 Experimental design of disinfection study. Shows the number of samples cleaned using each agent according to whether or not contact was made between the hoof knife blade and the BDD lesion for treatment purposes 
treponeme phylogroups. These were carried out using previously described primers [35] and Firepol ${ }^{\circ}$ Taq polymerase (Solis Biodyne, Estonia) according to manufacturer's instructions. Reaction conditions were as previously described [35], with an initial step using universal 16SrRNA gene bacterial primers, followed by a Treponema genus or phylogroup-specific nested PCR step, resulting in products which are $300-500 \mathrm{bp}$ elements of the 16S rRNA gene. All reactions were carried out in triplicate and validated using gDNA from each BDD treponeme phylogroup as positive controls and double distilled water as negative controls [35].

PCR products were visualised after electrophoresis through 1\% Agarose (Biorad, Hemel Hempstead, UK) and stained with $0.5 \mathrm{mg} / \mathrm{ml}$ ethidium bromide. PCR products were compared against $100 \mathrm{bp}$ and $1 \mathrm{~kb}$ DNA ladders (ThermoFisher Scientific, Waltham, USA) for size determination. Electric current was supplied by Biorad Powerpac 300 (Biorad, Hemel Hempstead, UK) at $120 \mathrm{~V}, 400 \mathrm{~mA}$ for $45 \mathrm{~min}$. Following electrophoresis, gels were transferred to a UV Illuminator, and images visualised and captured using a Geldoc gel documentation instrument and the GeneSys computer program (ThermoFisher Scientific).

\section{Statistical analyses}

Univariable logistic regression was performed using STATA v14 (Statacorp, USA) to test whether contact between the hoof knife blade and the lesion, or the lesion stage, explained the outcome of post-trimming cultures. Each disinfectant used was tested as an explanatory variable for the outcome of detection of BDD-associated phylogroup and/ or Treponema genus DNA post-disinfection.

\section{Supplementary information}

Supplementary information accompanies this paper at https://doi.org/10. 1186/s12917-020-02552-8.

Additional file 1: Table 1. Detection of the Treponema genus $(T)$ and three BDD treponeme phylogroups $(1,2,3)$ on 133 hoof knives during foot-trimming, using direct PCR of swabs and PCR of gDNA extracted from swab samples cultured for 6 weeks under anaerobic conditions.

\section{Acknowledgements}

The authors wish to thank the farmers and foot-trimmers who participated in the study.

\section{Authors' contributions}

All authors were involved in the conception and design of the study. RB, AG and GS collected the samples. AG and GS carried out laboratory work. AG, SC and NE analysed and interpreted the data. AG, SC and NE drafted the initial manuscript. All authors approved the final manuscript.

\section{Funding}

This work was funded by the BBSRC and AHDB Dairy. Apart from approving the initial concept, funding bodies did not have a role in study design, sample collection, data analysis, interpretation of data or writing of the manuscript.
Availability of data and materials

All data relevant to the study are included in the manuscript and supplementary information.

Ethics approval and consent to participate

This study was approved by the University of Liverpool Veterinary Research Ethics Committee (Ref: VREC662). Animal owners were provided with full information regarding the study before giving written consent for their cattle to be used in the study.

Consent for publication

Not applicable.

\section{Competing interests}

The authors declare that they have no competing interests.

\section{Author details}

'Department of Infection Biology, Institute of Infection and Global Health, University of Liverpool, Merseyside, UK. Wood Veterinary Group, 125 Bristol Road, Gloucester GL2 4NB, UK.

Received: 4 May 2020 Accepted: 31 August 2020

Published online: 11 September 2020

References

1. Cheli R, Mortellaro C. La dermatite digitale del bovino. In: Proceedings of the 8th International Conference on Diseases of Cattle; 1974. p. 208-13.

2. Rebhun WC, Payne RM, King JM, Wolfe M, Begg SN. Interdigital papillomatosis in dairy cattle. J Am Vet Med Assoc. 1980;177(5):437-40.

3. Peterse DJ. No. In: Proceedings of the 14th International Meeting on Diseases of Cattle; 1986.

4. Blowey RW. Digital dermatitis in dairy cattle. Vet Rec. 1987;121(13):311.

5. Holzhauer M, Hardenberg C, Bartels CJM, Frankena K. Herd- and cow-level prevalence of digital dermatitis in the Netherlands and associated risk factors. J Dairy Sci. 2006:89(2):580-8.

6. Capion N, Thamsborg SM, Enevoldsen C. Prevalence and severity of foot lesions in Danish Holstein heifers through first lactation. Vet J. 2009;182(1): $50-8$

7. Oliveira VHS, Sørensen JT, Thomsen PT. Associations between biosecurity practices and bovine digital dermatitis in Danish dairy herds. J Dairy Sci. 2017;100(10):8398-408.

8. Yang DA, Laven RA, Heuer C, Vink WD, Chesterton RN. Farm level risk factors for bovine digital dermatitis in Taranaki, New Zealand: an analysis using a Bayesian hurdle model. Vet J. 2018;234:91-5.

9. Döpfer D, Koopmans A, Meijer FA, Szakall I, Schukken YH, Klee W, et al. Histological and bacteriological evaluation of digital dermatitis in cattle, with special reference to spirochaetes and campylobacter faecalis. Vet Rec. 1997;140(24):620-3.

10. Berry SL, Read DH, Famula TR, Mongini A, Döpfer D. Long-term observations on the dynamics of bovine digital dermatitis lesions on a California dairy after topical treatment with lincomycin HCl. Vet J. 2012;193(3):654-8.

11. Choi BK, Nattermann H, Grund S, Haider W, Gobel UB. Spirochetes from digital dermatitis lesions in cattle are closely related to treponemes associated with human periodontitis. Int J Syst Bacteriol. 1997;47(1):175-81.

12. Collighan RJ, Woodward MJ. Spirochaetes and other bacterial species associated with bovine digital dermatitis. FEMS Microbiol Lett. 2006;156(1): 37-41 Available from: http://www.ncbi.nlm.nih.gov/pubmed/9368358. [cited 2019 Aug 1].

13. Evans NJ, Brown JM, Demirkan I, Murray RD, Vink WD, Blowey RW, et al. Three unique groups of spirochetes isolated from digital dermatitis lesions in UK cattle. Vet Microbiol. 2008;130(1-2):141-50.

14. Evans NJ, Brown JM, Demirkan I, Murray RD, Birtles RJ, Hart CA, et al. Treponema pedis sp. nov., a spirochaete isolated from bovine digital dermatitis lesions. Int J Syst Evol Microbiol. 2009;59(Pt 5):987-91.

15. Kuhnert P, Brodard I, Alsaaod M, Steiner A, Stoffel MH, Jores J. Treponema phagedenis (Ex noguchi 1912) brumpt 1922 sp. nov., nom. rev., isolated from bovine digital dermatitis. Int J Syst Evol Microbiol. 2020;70(3):2115-23 Available from: https://pubmed-ncbi-nlm-nih-gov.liverpool.idm.oclc.org/31 999237/. [cited 2020 Jul 9]. 
16. Beninger C, Naqvi SA, Naushad S, Orsel K, Luby C, Derakhshani H, et al. Associations between digital dermatitis lesion grades in dairy cattle and the quantities of four Treponema species. Vet Res. 2018:49(1):111.

17. Somers JGCJ, Frankena K, Noordhuizen-Stassen EN, Metz JHM. Risk factors for digital dermatitis in dairy cows kept in cubicle houses in the Netherlands. Prev Vet Med. 2005;71(1-2):11-21.

18. Evans NJ, Timofte D, Isherwood DR, Brown JM, Williams JM, Sherlock K, et al. Host and environmental reservoirs of infection for bovine digital dermatitis treponemes. Vet Microbiol. 2012;156(1-2):102-9.

19. Wells SJ, Garber LP, Wagner BA. Papillomatous digital dermatitis and associated risk factors in US dairy herds. Prev Vet Med. 1999:38:11-24.

20. Sullivan LE, Blowey RW, Carter SD, Duncan JS, Grove-White DH, Page P, et al. Presence of digital dermatitis treponemes on cattle and sheep hoof trimming equipment. Vet Rec. 2014;175(8):201.

21. Rock C, Krull A, Gorden P, Shearer J, Plummer P. Metagenomic evaluation of the dairy farm environment and facilities for evidence of digital dermatitis associated bacteria. Proceedings of the International Symposium and Conference on Lameness in Ruminants - Valdivia, Chile - 2015. 2015. Available from: http://www.ivis.org.

22. Gillespie A, Carter SD, Blowey RW, Evans N. Survival of bovine digital dermatitis treponemes on hoof knife blades and the effects of various disinfectants. Vet Rec. 2019:186:67.

23. Hartshorn RE, Thomas EC, Anklam K, Lopez-Benavides MG, Buchalova M, Hemling TC, et al. Short communication: minimum bactericidal concentration of disinfectants evaluated for bovine digital dermatitisassociated Treponema phagedenis-like spirochetes. J Dairy Sci. 2013;96(5): 3034-8

24. Angell JW, Clegg SR, Grove-White DH, Blowey RW, Carter SD, Duncan JS, et al. Survival of contagious ovine digital dermatitis (CODD)-associated treponemes on disposable gloves after handling CODD-affected feet. Vet Rec. 2017;181(4):89.

25. Holzhauer M, Bartels CJ, Bergsten C, van Riet MMJ, Frankena K, Lam TJGM. The effect of an acidified, ionized copper sulphate solution on digital dermatitis in dairy cows. Vet J. 2012;193(3):659-63.

26. Solano L, Barkema HW, Jacobs C, Orsel K. Validation of the M-stage scoring system for digital dermatitis on dairy cows in the milking parlor. J Dairy Sci. 2017;100(2):1592-603.

27. Biemans F, Bijma P, Boots NM, de Jong MCM. Digital Dermatitis in dairy cattle: The contribution of different disease classes to transmission. Epidemics. Elsevier B.V. 2018;23:76-84.

28. Eisenberg SWF, Nielen M, Santema W, Houwers DJ, Heederik D, Koets AP. Detection of spatial and temporal spread of Mycobacterium avium subsp. paratuberculosis in the environment of a cattle farm through bio-aerosols. Vet Microbiol. 2010;143(2-4):284-92.

29. Ravva SV, Sarreal CZ, Mandrell RE. Bacterial Communities in Aerosols and Manure Samples from Two Different Dairies in Central and Sonoma Valleys of California. Gillbert J, editor. PLoS One. 2011;6(2):e17281 Available from: https://dx.plos.org/10.1371/journal.pone.0017281.

30. Read D, Walker R. Experimental transmission of papillomatous digital dermatitis (footwarts) in cattle. Vet Pathol. 1996;33:607.

31. Gomez A, Cook NB, Bernardoni ND, Rieman J, Dusick AF, Hartshorn R, et al. An experimental infection model to induce digital dermatitis infection in cattle. J Dairy Sci. 2012;95(4):1821-30

32. Krull AC, Cooper VL, Coatney JW, Shearer JK, Gorden PJ, Plummer PJ. A highly effective protocol for the rapid and consistent induction of digital dermatitis in Holstein calves. PLoS One. 2016;11(4):e0154481.

33. Bay V, Griffiths B, Carter S, Evans NJ, Lenzi L, Bicalho RC, et al. $16 \mathrm{~S}$ rRNA amplicon sequencing reveals a polymicrobial nature of complicated claw horn disruption lesions and interdigital phlegmon in dairy cattle. Sci Rep. 2018;8:15529.

34. Chua PKB, Corkill JE, Hooi PS, Cheng SC, Winstanley C, Hart CA. Isolation of Waddlia malaysiensis, A Novel Intracellular Bacterium, from Fruit Bat ( Eonycteris spelaea ). Emerg Infect Dis. 2005;11(2):271-7.

35. Evans NJ, Brown JM, Demirkan I, Singh P, Getty B, Timofte D, et al. Association of unique, isolated treponemes with bovine digital dermatitis lesions. J Clin Microbiol. 2009:47(3):689-96.

\section{Publisher's Note}

Springer Nature remains neutral with regard to jurisdictional claims in published maps and institutional affiliations.

Ready to submit your research? Choose BMC and benefit from:

- fast, convenient online submission

- thorough peer review by experienced researchers in your field

- rapid publication on acceptance

- support for research data, including large and complex data types

- gold Open Access which fosters wider collaboration and increased citations

- maximum visibility for your research: over $100 \mathrm{M}$ website views per year

At $\mathrm{BMC}$, research is always in progress.

Learn more biomedcentral.com/submissions 